\title{
The effect of micro-electric current and other activation techniques on dissolution abilities of sodium hypochlorite in bovine tissues
}

\author{
Ihsan Furkan Ertuğrul ${ }^{1 *}$, Murat Maden ${ }^{1}$, Ekim Onur Orhan ${ }^{2}$ and Sabriye Perçin Özkorucuklu ${ }^{3}$
}

\begin{abstract}
Background: The aim of the study was to evaluate the effects of micro-electric current on sodium hypochlorite's ( $\mathrm{NaOCl}^{\prime} \mathrm{s}$ ) tissue-dissolution abilities, compared with other activation methods, including sonic, ultrasonic, pipetting, and temperature.

Methods: Bovine muscle tissues $(n=154)$ with standard sizes and weights were prepared and divided into two temperature groups: room temperature and $45^{\circ} \mathrm{C}$. Each temperature group was divided into seven sub-groups by activation methods: $\mathrm{D}=$ distilled water (-control); $\mathrm{NaOCl}=5.25 \%$ passive $\mathrm{NaOCl}$ (+ control); $P=5.25 \% \mathrm{NaOCl}$ with pipetting; $\mathrm{SA}=5.25 \% \mathrm{NaOCl}$ with sonic activation; $\mathrm{UA}=5.25 \% \mathrm{NaOCl}$ with ultrasonic activation; $\mathrm{E}-\mathrm{NaOCl}=5.25 \%$ $\mathrm{NaOCl}$ with micro-electric current; and $\mathrm{E}-\mathrm{NaOCl}+P=5.25 \% \mathrm{NaOCl}$ with micro-electric current and pipetting. Specimens were weighed before and after treatment. Average, standard deviation, minimum, maximum, and median were calculated for each group. Resulting data were analyzed statistically using multi-way ANOVA and Tukey HSD tests. The level of the alpha-type error was set at $<0.05$.

Results: At room temperature, the $\mathrm{E}-\mathrm{NaOCl}+\mathrm{P}$ group dissolved the highest amount of tissue $(p<0.05)$, and the $U A, S A$, and $P$ groups dissolved significantly higher amounts of tissue than did the positive control or $\mathrm{E}-\mathrm{NaOCl}$ groups $(p<0.05)$. At $45^{\circ} \mathrm{C}$, there was no significant difference between the $\mathrm{SA}$ and $\mathrm{E}-\mathrm{NaOCl}$ groups $(p>0.05)$, and the $\mathrm{E}-\mathrm{NaOCl}+\mathrm{P}$ group dissolved a higher amount of tissue than any other group $(p<0.05)$.

Conclusions: Using $\mathrm{NaOCI}$ with micro-electric current can improve the tissue-dissolving ability of the solution. In addition, this method can be combined with additional techniques, such as heating and/or pipetting, to achieve a synergistic effect of $\mathrm{NaOCl}$ on tissue dissolution.
\end{abstract}

Keywords: Dissolution, Micro direct current, Sodium hypochlorite, EndoActivator, Irrigation

\section{Background}

Successful root-canal treatment depends on removing micro-organisms, which cause infection of pulp tissue, and dentin debris from the root canal [1,2]. Irrigation plays an important role in efficient biomechanical preparation [3]. Residual pulpal tissue, infected dentin, and bacteria remnants in the root-canal system can cause failure of the root-canal treatment [4]. Due to its anti-microbial

\footnotetext{
* Correspondence: furkanertugrul@gmail.com

${ }^{1}$ Department of Endodontics, Ağız Diş Sağlığı Merkezi, Aydın, Turkey

Full list of author information is available at the end of the article
}

and soft-tissue dissolving characteristics, sodium hypochlorite $(\mathrm{NaOCl})$ is one of the most frequently used rootcanal irrigation solutions [5-7].

$\mathrm{NaOCl}$ has a dynamic balance that tends to change direction continuously, as the formula below shows [8].

$\mathrm{NaOCl}+\mathrm{H}_{2} \mathrm{O} \leftrightarrow \mathrm{NaOH}+\mathrm{HOCl} \leftrightarrow \mathrm{Na}^{+}+\mathrm{OH}^{-}+$ $\mathrm{H}^{+}+\mathrm{OCl}^{-}$.

External factors that change this dynamic balance also change $\mathrm{NaOCl}$ 's efficiency. Although $\mathrm{NaOCl}$ has many properties, activation techniques as an external factor affect the dynamic balance of $\mathrm{NaOCl}$ use, increasing its tissue dissolution ability, based on activation with sonic 
or ultrasonic devices, and heating the solution $[4,9,10]$. Increasing $\mathrm{NaOCl}$ 's temperature is accepted as an activation technique that increases the solution's dissolution effect, and increased anti-microbial activity and faster tissue dissolution have been reported by increasing the temperature of the $\mathrm{NaOCl}$ [11]. In addition, applying sonic waves increased the $\mathrm{NaOCl}$ solution's effect. The EndoActivator ${ }^{\mathrm{Tm}}$ (Dentsply-Maillefer, Ballaigues, Switzerland) is a popular instrument in dental practice that produces sonic waves during root-canal treatment. It was reported that $\mathrm{NaOCl}$ solution activated by the cyclic movement of the EndoActivator's polymer tip debrided residual tissue more effectively and successfully removed the smear layer [12]. Ultrasonic energy have been used together with $\mathrm{NaOCl}$ solution to create a synergistic effect, increasing effectiveness of $\mathrm{NaOCl}$ 's dissolution activity $[9,13]$.

Recently, we demonstrated that micro-electrical activated $\mathrm{NaOCl}$ increased the tissue dissolution capacity of the solution [14].

The null hypothesis was that the micro-electrical energy can increase the tissue dissolution efficiency of sodium hypochlorite solution as well as conventional activation methods such as heating, pippeting, sonic \& ultrasonic energy.

The purpose of this in vitro study was to compare micro-electric current activation with other methods, such as sonic, ultrasonic, and heat activation on the dissolution ability of $\mathrm{NaOCl}$.

\section{Methods}

This in vitro study conducted on bovine muscle model optained from a public butcher. Therefore authors stated that ethical approval from commitee of human or animal researches was not necessary.

Wizard $^{\text {Tw }}$ (Rehber Kimya San., Istanbul, Turkey) $\mathrm{NaOCl}$ solution, with a concentration of $5.25 \%$ chlorine was determined by the iodine/titration method. Prior to the experiments, the $\mathrm{NaOCl}$ concentration was kept at $+4{ }^{\circ} \mathrm{C}$.

Bovine muscle tissue was used for these tissuedissolution experiments. Muscle tissue was kept at $-16{ }^{\circ} \mathrm{C}$ and in a $100 \%$ humid medium. To standardize size and weight, samples were collected with a biopsy punch with a 5-mm diameter (Sterile Dermal Biopsy Punch; Kai Industries Ltd.; Seki, Japan) from a 2-mm tissue piece cut from muscle tissue. Prior to testing, samples were weighed with a digital precision scale (Presica 205a; Dietikon, Switzerland) and put in a $10-\mathrm{mL} \mathrm{NaOCl}$ solution. Before treatment with $\mathrm{NaOCl}$, mean weight of tissue samples was $38 \pm 1 \mathrm{mg}$.

In accordance with a study by Stojicic et al., the experiments were conducted at room temperature $\left(25^{\circ} \mathrm{C}\right)$ and at $45{ }^{\circ} \mathrm{C}$ [10]. Experiments conducted at room temperature were performed in containers in an acclimatized room. For those experiments conducted at $45{ }^{\circ} \mathrm{C}$, a temperaturecontrolled water bath (Wisebath; Daihan Scientific Ltd.; South Korea) kept the containers at $45{ }^{\circ} \mathrm{C}$. To confirm temperatures, tests used an external thermometer (Acrol Scientific Laboratory Systems; İstanbul, Turkey).

Specimens were divided into two groups according to temperature. Then, each temperature groups was subdivided into 7 groups by activation methods. These 14 groups contained 154 tissue samples, 11 in each group (Table 1). For each sample, the duration of the experiment conducted was $5 \mathrm{~min}$. Sterile distilled water (D) was used for the negative control group, and $5.25 \%$ $\mathrm{NaOCl}$ solution without any activation was used for the positive control group.

The experiments tested 3 current-activation methods: ultrasonic (UA), sonic (SA), and pipetting (P). In the ultrasonic experiments, the stainless steel size \#25 ultrasonic tip (DT-007, Electro Medical Systems, Nyon, Switzerland) was operated at moderate speed in the solution. The EndoActivator ${ }^{\text {ra }}$ using polymer tip no. 25/04 was run at $10,000 \mathrm{cpm}$ in the solution. Tips used in ultrasonic and sonic activation were submerged up to $10 \mathrm{~mm}$ in the $\mathrm{NaOCl}$ solution and operated at a distance of approximately $5 \mathrm{~mm}$ from the tissue. For pipetting, in accordance with Stojicic et al. [10], a glass stirring rod (Acrol Scientific Laboratory Systems; İstanbul, Turkey) was mechanically activated by the same operator at a distance of $5 \mathrm{~mm}$ from the tissue. Current-activation procedures were performed for $15 \mathrm{~s}$ each minute during the 5-min experiment period.

In addition, 2 micro-electric methods were used in the experiments: single micro-electric energy $(\mathrm{E}-\mathrm{NaOCl})$ and micro-electric energy with pipetting $(\mathrm{E}-\mathrm{NaOCl}+\mathrm{P})$. A potentiometer (Autolab; Utrecht, Holland) was calibrated to supply $10 \mathrm{~mA}$ to the $\mathrm{NaOCl}$ (Fig. 1). To test creation of the synergistic effect, the micro-electric and pipetting procedures were applied to the $\mathrm{NaOCl}$ solution together.

Table 1 "D", Distilled water (-control); "NaOCl", 5.25 \% Passive $\mathrm{NaOCl}$ (+ control); "P", $5.25 \% \mathrm{NaOCl}$ with pipetting; "SA", $5.25 \%$ $\mathrm{NaOCl}$ with sonic motion device; "UA", $5.25 \% \mathrm{NaOCl}$ with ultrasonic motion device; "E-NaOCl", 5,25 \% NaOCl with micro electricity; "E-NaOCl$+\mathrm{P}$ ", $5 \% \mathrm{NaOCl}$ with micro electricity + pipetting

\begin{tabular}{lll}
\hline$n$ & Room temperature groups & $45^{\circ} \mathrm{C}$ groups \\
\hline 11 & $\mathrm{D}$ & $\mathrm{D}$ \\
11 & $\mathrm{NaOCl}$ & $\mathrm{NaOCl}$ \\
11 & $\mathrm{P}$ & $\mathrm{P}$ \\
11 & $\mathrm{SA}$ & $\mathrm{SA}$ \\
11 & $\mathrm{UA}$ & $\mathrm{UA}$ \\
11 & $\mathrm{E}-\mathrm{NaOCl}$ & $\mathrm{E}-\mathrm{NaOCl}$ \\
11 & $\mathrm{E}-\mathrm{NaOCl}+\mathrm{P}$ & $\mathrm{E}-\mathrm{NaOCl}+\mathrm{P}$ \\
\hline
\end{tabular}




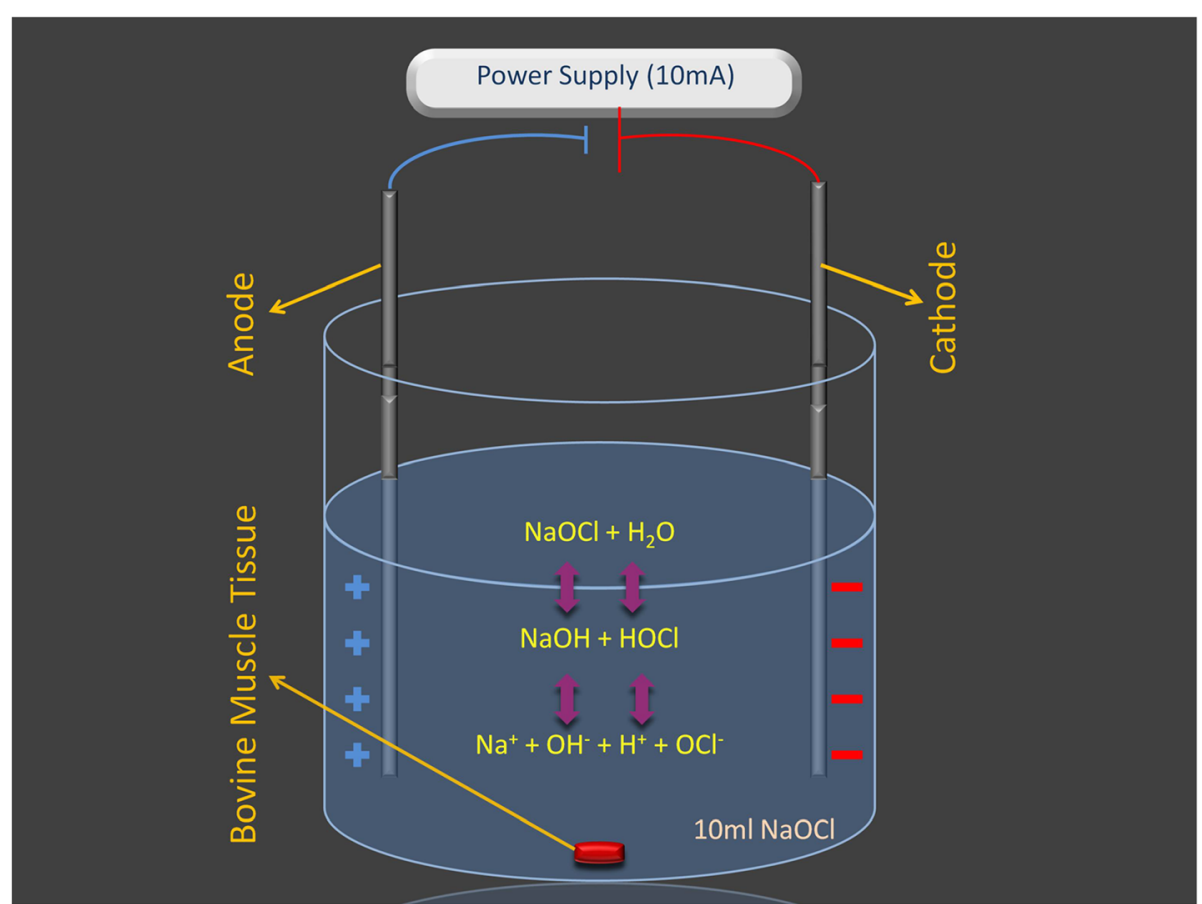

Fig. 1 Effects of micro-electric current on NaOCl's dissolution activity on bovine tissue. NaOCl shows a dynamic balance

After $5 \mathrm{~min}$, each sample was taken out of the solution, dried gently, and re-weighed. The percentage of the weight lost was calculated. Data were analyzed statistically using multi-way ANOVA and Tukey HSD tests. The level of the alpha-type error was set at $<0.05$.

\section{Results}

Figure 2 shows the percentage of weight lost by groups. Average, standard deviation, minimum, maximum, and median were calculated for each group.

All activation groups at both temperatures dissolved significantly higher amounts of tissue than did the negative control groups $(P<0.001)$. At room temperature, the $\mathrm{UA}, \mathrm{SA}$, and $\mathrm{P}$ groups dissolved significantly higher amounts of tissue than did the $\mathrm{E}-\mathrm{NaOCl}$ group $(P<0.001$ for both comparisons), and the $\mathrm{E}-\mathrm{NaOCl}+\mathrm{P}$ group dissolved the highest amount of tissue $(p<0.05)$.

As Table 2 shows, the subgroups at $45{ }^{\circ} \mathrm{C}$ dissolved significantly higher amounts of tissue than did the subgroups at room temperature. $(P<0.05)$. At $45{ }^{\circ} \mathrm{C}$, the $\mathrm{UA}$ and $\mathrm{P}$ groups dissolved significantly higher amounts of tissue than did the E-NaOCl group $(P<0.001$ for both comparisons). The $\mathrm{E}-\mathrm{NaOCl}+\mathrm{P}$ group dissolved higher amounts of tissue than did any other group, including those groups at room temperature $(P<0.05)$.

\section{Discussion}

Many studies have been conducted on the tissue-dissolving abilities of $\mathrm{NaOCl}$. These studies have demonstrated that
NaOCl's dissolution effect changes as its concentration, $\mathrm{pH}$, surface tension, and temperature change. In addition, agitation methods increase $\mathrm{NaOCl}$ 's dissolution effect $[4,10,15,16]$. Previous tissue-dissolution studies have used various tissues, including rat connective tissue [15], pork palatal mucosa [17], pork muscle [3], rabbit liver [4], bovine pulp [18], and bovine muscle [16]. The present study chose bovine muscle tissue instead of pulp tissue so as to be able to standardize both surface area and weight with a tissue punch.

Lumley et al. determined $100 \mu \mathrm{m}$ and less to be the distance limit for creating cavitation during ultrasonic action [19]. In the present study, ultrasonic and sonic tips were operated at a distance of $5 \mathrm{~mm}$ from the tissue in all experiments, thus avoiding the cavitation effect. Sirtes et al. determined that, at $45^{\circ} \mathrm{C}$, the concentration of chlorine in $5.25 \% \mathrm{NaOCl}$ solution did not change for $1 \mathrm{~h}$ [20]. Therefore, in the present study, heated $\mathrm{NaOCl}$ was not kept more than $1 \mathrm{~h}$ in the experiments conducted at $45{ }^{\circ} \mathrm{C}$. Our results presented that the dissolution ability of heated $\mathrm{NaOCl}$ to be superior, similar to the results obtained by previous studies on the effects of temperature on tissue dissolution [20-22].

We reported, for the first time, that micro electrically activated $5.25 \% \mathrm{NaOCl}$ has better results than $5.25 \%$ $\mathrm{NaOCl}$ without any activation on tissue dissolution efficiency [14]. Micro electric currents and sonic waves showed synergic tissue dissolution efficiency $(p<0.05)$. We also obtained positive combination results on $\mathrm{NaOCl}$ 


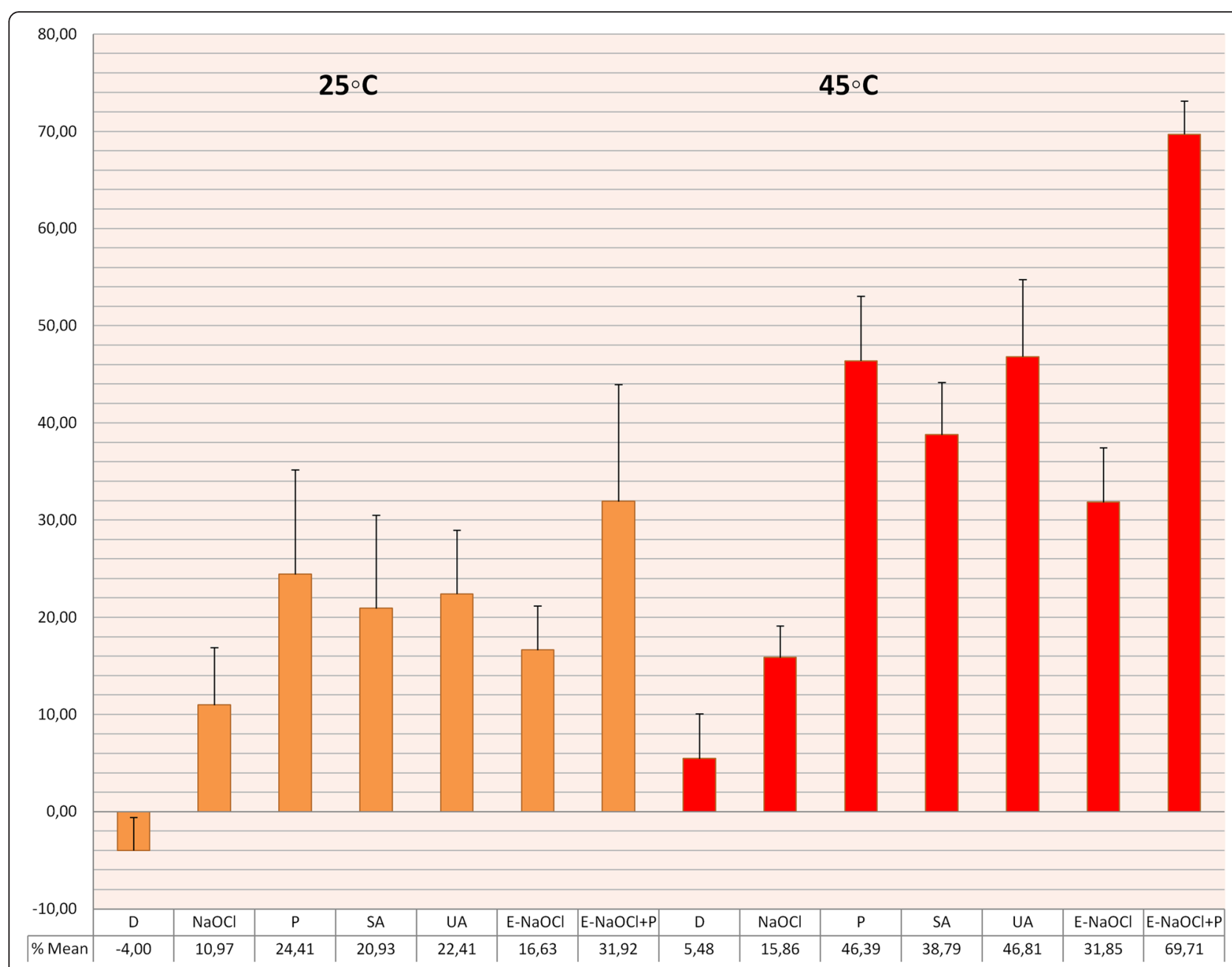

Fig. 2 Bar chart depicting relative amounts (percent of original weight) of remaining bovine tissue, $(n=11$ per group) after treatment with $10 \mathrm{ml}$ of $\mathrm{NaOCl}$

Table 2 Effect of four five methods of activation on tissue dissolution (\% tissue weight loss \pm standard deviation) by the $5 \% \mathrm{NaOCl}$ solutions

\begin{tabular}{llll}
\hline$n$ & & $25 \mathrm{C}$ & $45 \mathrm{C}$ \\
\hline 11 & Distilled water & $4.11 \pm 3.41^{\mathrm{a}}$ & $-5.48 \pm 4.56^{\mathrm{f}}$ \\
11 & $5 \% \mathrm{NaOCl}$ & $-10.97 \pm 5.93^{\mathrm{b}}$ & $-15.86 \pm 3.27^{\mathrm{d}}$ \\
11 & $5 \% \mathrm{NaOCl}$ with pipetting & $-24.41 \pm 10.78^{\mathrm{c}}$ & $-46.39 \pm 6.66^{\mathrm{t}}$ \\
11 & $5 \% \mathrm{NaOCl}$ with sonic energy & $-20.93 \pm 9.56^{\mathrm{cd}}$ & $-38.79 \pm 5.38^{\mathrm{te}}$ \\
11 & $5 \% \mathrm{NaOCl}$ with ultrasonic energy & $-22.41 \pm 6.53^{\mathrm{c}}$ & $-46.81 \pm 7.94^{\mathrm{t}}$ \\
11 & $5 \% \mathrm{E}-\mathrm{NaOCl}$ & $-16.63 \pm 4.54^{\mathrm{d}}$ & $-31.85 \pm 5.61^{\mathrm{e}}$ \\
11 & $5 \% \mathrm{E}-\mathrm{NaOCl}$ with pipetting & $-31.92 \pm 12.04^{\mathrm{e}}$ & $-69.71 \pm 3.41^{\mathrm{s}}$
\end{tabular}

The same superscript letters are demonstrate no significant differences $(p<0.05)$ activated with micro-electric current, heat, and agitation methods on NaOCl's tissue-dissolving ability. This can be explained by the finding that when a micro electric current is activated $\mathrm{NaOCl}$, the dynamic balance of the solution may change.

The present study found no significant difference between sonic, ultrasonic, and pipetting activation at room temperature. These results conform to those found by Stojicic et al. [10]. Conventional agitation methods such as ultrasonic and sonic energy were tested. The ultrasonic activation showed greater tissue dissolution than nonactivated $\mathrm{NaOCl}(P<0.0001)$. Some previous studies have demonstrated that ultrasonic-activated $\mathrm{NaOCl}$ cleaned root canals successfully [23-25]. However, other researchers found no difference between ultrasonic and conventional syringe irrigation of the root canal [26-28]. The difference in results may be related to the volume and concentration of $\mathrm{NaOCl}$, the power settings used, and/or the duration of treatment with ultrasonic activation. 
In previous studies, electrolysed water was used as a canal-washing solution [29, 30]. In the present study, $10 \mathrm{~mA}$ direct current was created between the anode and cathode to change the dynamic structure of $\mathrm{NaOCl}$, and the direct current was passed through the $\mathrm{NaOCl}$ solution at a micro level. This procedure differed methodologically from previous studies conducted with electrolysed water. Our results may not be directly extrapolated to the clinical conditions, however a direct microcurrent applied with a potentiostat-like device may increase the tissue dissolution capacity which has a similar performance like preheated sodium hypochlorite. Moreover this activation method may also be combined with conventional activation systems such as EndoActivator ${ }^{\mathrm{TM}}$ or any sonic system during the final irrigation.

\section{Conclusions}

Within the limitations of the present study combined use of micro-electric energy, heat, and agitation had a positive, synergistic effect on sodium hypochlorite's tissue-dissolving ability. However, further studies should be conducted on the micro-electric energy to better understand this technique in practice.

\section{Abbreviations \\ $\mathrm{NaOCl}$ : Sodium hypochlorite solution; D: Distilled water (-control); NaOCl: $5.25 \%$ passive sodium hypochlorite solution (+ control); P: $5.25 \%$ Sodium hypochlorite solution with pipetting: $\mathrm{SA}=5.25 \% \mathrm{NaOCl}$ with sonic activation; $\mathrm{E}-\mathrm{NaOCl}+\mathrm{P}: 5.25 \%$ sodium hypochlorite solution with micro- electric current and pipetting; UA: $5.25 \%$ sodium hypochlorite solution with ultrasonic activation; E-NaOCl: $5.25 \%$ sodium hypochlorite solution with micro-electric current.}

\section{Competing interests}

The author declares that there are no conflicts of interest.

\section{Authors' contributions}

IFE: Idea, performed experiments, performed the statistical analysis. MM: Supervisor of the study, experimental designer of tissue dissolution tests, proofread manuscript. EOO: Co-supervisor of the writing the manuscript. Sabriye SPO: Co-supervisor of Electrolysis experiments. All authors read and approved the final manuscript.

\section{Authors' information}

1. İhsan Furkan Ertuğrul, DDs, PhD Department of Endodontics, Ağız Diş Sağlığı Merkezi, Aydın Turkey. Mail: furkanertugrul@gmail.com. 2. Murat Maden, DDS, PhD, Department of Endodontics, Faculty of Dentistry, Süleyman Demirel University Isparta Turkey. Mail: mmaden@dishek.sdu.edu.tr. 3. Ekim Onur Orhan, DDS, PhD, Department of Endodontics, Faculty of Dentistry, Osmangazi University, Eskişehir, Turkey. Mail: eonurdentus@hotmail.com.

4. Sabriye Perçin Özkorucuklu, PhD, Department of Chemistry, Faculty of Science and Art, Süleyman Demirel University Isparta Turkey. Mail: sabriyeozkorucuklu@sdu.edu.tr.

\section{Acknowledgement}

We thanks to Suleyman Demirel University, Chemistry Laboratory.

\section{Author details}

'Department of Endodontics, Ağız Diş Sağlığı Merkezi, Aydın, Turkey. 2Department of Endodontics, Faculty of Dentistry, Osmangazi University, Eskişehir, Turkey. ${ }^{3}$ Department of Chemistry, Faculty of Science and Art, Süleyman Demirel University, Isparta, Turkey.
Received: 24 September 2015 Accepted: 14 December 2015

Published online: 18 December 2015

\section{References}

1. Abbott PV. The periapical space a dynamic interface. Aust Endod J. 2002;28: 96-107.

2. Goldman LB, Goldman M, Kronman JH, Lin PS. The efficacy of several irrigating solutions for endodontics: a scanning electron microscopic study. Oral Surg Oral Med Oral Pathol. 1981;52:197-204.

3. Hasselgren G, Olsson B, Cvek M. Effects of calcium hydroxide and sodium hypochlorite on the dissolution of necrotic porcine muscle tissue. J Endod. 1988;14:125-7

4. Moorer WR, Wesselink PR. Factors promoting the tissue dissolving capability of sodium hypochlorite. Int Endod J. 1982;15:187-96.

5. Clarkson RM, Kidd B, Evans GE, Moule AJ. The effect of surfactant on the dissolution of porcine pulpal tissue by sodium hypochlorite solutions. J Endod. 2012;38:1257-60.

6. Rosenfeld EF, James GA, Burch BS. Vital pulp tissue response to sodium hypochlorite. J Endod. 1978;4:140-6.

7. Sassone LM, Fidel RA, Murad CF, Fidel SR, Hirata Jr R. Antimicrobial activity of sodium hypochlorite and chlorhexidine by two different tests. Aust Endod J Inc. 2008:34:19-24.

8. Estrela C, Estrela CR, Barbin EL, Spano JC, Marchesan MA, Pecora JD. Mechanism of action of sodium hypochlorite. Braz Dent J. 2002:13:113-7.

9. Cunningham WT, Balekjian AY. Effect of temperature on collagen-dissolving ability of sodium hypochlorite endodontic irrigant. Oral Surg Oral Med Oral Pathol. 1980;49:175-7

10. Stojicic S, Zivkovic S, Qian W, Zhang H, Haapasalo M. Tissue dissolution by sodium hypochlorite: effect of concentration, temperature, agitation, and surfactant. J Endod. 2010;36:1558-62.

11. Zehnder M. Root canal irrigants. J Endod. 2006;32:389-98.

12. Cj R. Endodontic disinfection: tsunami irrigation. Endod Practice. 2008;11:7-15.

13. Lee SJ, Wu MK, Wesselink PR. The effectiveness of syringe irrigation and ultrasonics to remove debris from simulated irregularities within prepared root canal walls. Int Endod J. 2004;37:672-8.

14. Ertugrul IF, Maden M, Orhan EO, Ozkorucuklu SP, Aglarca AV. Rapid tissue dissolution efficiency of electrically-activated sodium hypochlorite on bovine muscle. Eur J Dent. 2014;8:464-8.

15. Hand RE, Smith ML, Harrison JW. Analysis of the effect of dilution on the necrotic tissue dissolution property of sodium hypochlorite. J Endod. 1978:4:60-4.

16. Turkun M, Cengiz T. The effects of sodium hypochlorite and calcium hydroxide on tissue dissolution and root canal cleanliness. Int Endod J. 1997;30:335-42.

17. Naenni N, Thoma K, Zehnder M. Soft tissue dissolution capacity of currently used and potential endodontic irrigants. J Endod. 2004;30:785-7.

18. Okino LA, Siqueira EL, Santos M, Bombana AC, Figueiredo JA. Dissolution of pulp tissue by aqueous solution of chlorhexidine digluconate and chlorhexidine digluconate gel. Int Endod J. 2004;37:38-41.

19. Lumley PJ, Walmsley AD, Laird WR. Streaming patterns produced around endosonic files. Int Endod J. 1991;24:290-7.

20. Sirtes G, Waltimo T, Schaetzle M, Zehnder M. The effects of temperature on sodium hypochlorite short-term stability, pulp dissolution capacity, and antimicrobial efficacy. J Endod. 2005:31:669-71.

21. Abou-Rass M, Oglesby SW. The effects of temperature, concentration, and tissue type on the solvent ability of sodium hypochlorite. J Endod. 1981;7:376-7.

22. Rossi-Fedele G, De Figueiredo JA. Use of a bottle warmer to increase 4\% sodium hypochlorite tissue dissolution ability on bovine pulp. Aust Endod J. 2008;34:39-42

23. Ahmad M, Pitt Ford TJ, Crum LA. Ultrasonic debridement of root canals: acoustic streaming and its possible role. J Endod. 1987;13:490-9.

24. Cameron JA. The synergistic relationship between ultrasound and sodium hypochlorite: a scanning electron microscope evaluation. J Endod. 1987;13:541-5.

25. Sabins RA, Johnson JD, Hellstein JW. A comparison of the cleaning efficacy of short-term sonic and ultrasonic passive irrigation after hand instrumentation in molar root canals. J Endod. 2003:29:674-8.

26. Cymerman JJ, Jerome LA, Moodnik RM. A scanning electron microscope study comparing the efficacy of hand instrumentation with ultrasonic instrumentation of the root canal. J Endod. 1983;9:327-31. 
27. Mayer BE, Peters OA, Barbakow F. Effects of rotary instruments and ultrasonic irrigation on debris and smear layer scores: a scanning electron microscopic study. Int Endod J. 2002;35:582-9.

28. Tauber $R$, Morse DR, Sinai IA, Furst ML. A magnifying lens comparative evaluation of conventional and ultrasonically energized filing. J Endod. 1983;9:269-74

29. Qing Y, Akita Y, Kawano S, Kawazu S, Yoshida T, Sekine I. Cleaning efficacy and dentin micro-hardness after root canal irrigation with a strong acid electrolytic water. J Endod. 2006;32:1102-6.

30. Solovyeva AM, Dummer PM. Cleaning effectiveness of root canal irrigation with electrochemically activated anolyte and catholyte solutions: a pilot study. Int Endod J. 2000;33:494-504.

Submit your next manuscript to BioMed Central and we will help you at every step:

- We accept pre-submission inquiries

- Our selector tool helps you to find the most relevant journal

- We provide round the clock customer support

- Convenient online submission

- Thorough peer review

- Inclusion in PubMed and all major indexing services

- Maximum visibility for your research

Submit your manuscript at www.biomedcentral.com/submit 